CHAPTER ।

\title{
Preface: Guy Debord, Donald Trump, and the Politics of the Spectacle
}

\author{
Douglas Kellner
}

Guy Debord described a 'society of the spectacle' in which the economy, politics, social life, and culture were increasingly dominated by forms of spectacle. ${ }^{1}$ This collected volume updates Debord's theory of the spectacle for the twentyfirst century and the age of digital media and digital capitalism. We now live in an era, where the digitally mediated spectacle has contributed to right-wing authoritarian populist Donald Trump becoming US president, and Debord's concept of spectacle is now more relevant than ever to interpreting contemporary culture, society, and politics.

Donald Trump lived the spectacle from the time in New York when as a young entrepreneur and man about town he performed his business and personal life in gossip columns, tabloids, and rumor mills. Trump used PR advisors to promote both his businesses and his persona to eventually become a maestro of the spectacle when his popular TV show The Apprentice made him into a national celebrity. Trump ran his 2016 presidential campaign as a media spectacle with daily tweets that became fodder for TV news, and with rallies where he would make outrageous comments that would be replayed endlessly on cable and network news. Trump thus dominated news cycles by creating daily spectacles of political attack, insulting and negatively defining opponents,

How to cite this book chapter:

Kellner, D. 2017. Preface: Guy Debord, Donald Trump, and the Politics of the Spectacle. In: Briziarelli, M. and Armano, E. (eds.). The Spectacle 2.0: Reading Debord in the Context of Digital Capitalism. Pp. 1-13. London: University of Westminster Press. DOI: https://doi.org/10.16997/book11.a. License: CC-BY-NC-ND 4.0 
thus helping to construct daily media events through which he was able to define the news agenda.

Hence, I argue that the election of Donald J. Trump in the 2016 US presidential election is the culmination of the politics of the spectacle that was first described by Debord. Explaining the Trump phenomenon is a challenge that will occupy critical theorists of US politics for years to come. My first take on the Trump phenomenon is that Donald Trump won the Republican primary contest and then achieved a shocking upset victory in the 2016 US Presidential Election because he is a master of media spectacle, a concept that I have been developing and applying to US politics and media since the mid-1990s. ${ }^{2}$ In this study, I will first discuss Trump's use of media spectacle in his business career, in his effort to become a celebrity and reality TV superstar, and in his political campaign out of which he emerged as President of the United States of Spectacle. ${ }^{3}$

\section{Donald Trump: Master of Media Spectacle}

I first proposed the concept of media spectacle to describe the key phenomenon of US media and politics in the mid-1990s. This was the era of the O.J. Simpson murder case and trial, the Clinton sex scandals, and the rise of cable news networks like Fox, CNN, and MSNBC and the 24/7 news cycle that has dominated US politics and media since then. ${ }^{4}$ The 1990s was also the period when the Internet and new media took off so that anyone could be a political commentator, player, and participant in the spectacle, a phenomenon that accelerated as new media morphed into social media and teenagers, celebrities, politicians, and others who wanted to become part of the networked virtual world and interactive spectacle joined in.

The scope of the spectacle has thus increased in the past decades with the proliferation of new media and social networking like Facebook, YouTube, Twitter, Instagram, Skype, and so on, which increase the scope and participation of the spectacle, and make Debord's concept of the spectacle all the more relevant in the contemporary era. By 'media spectacles' I am referring to media constructs that present events which disrupt ordinary and habitual flows of information. These become popular stories which capture the attention of the media and the public, and circulate through broadcasting networks, the Internet, social networking, smart phones, and other new media and communication technologies. In a globally networked society, media spectacles proliferate instantaneously, become virtual and viral, and in some cases, becomes tools of socio-political transformation, while other media spectacles become mere moments of media hype and tabloidized sensationalism.

Dramatic news events are presented as media spectacles and dominate certain news cycles. Stories like the 9/11 terror attacks, Hurricane Katrina, Barack Obama and the 2008 US presidential election, and in 2011 the Arab Uprisings, 
the Libyan revolution, the UK Riots, the Occupy movement and other major media spectacles of the era, cascaded through broadcasting, print, and digital media, seizing people's attention and emotions, and generating complex and multiple effects that may make 2011 as memorable a year in the history of social upheaval as 1968, the year in which events in France decisively shaped Debord's dialectic of spectacle and insurrection, a model still highly relevant today. ${ }^{5}$

In today's highly competitive media environment, 'Breaking News!' of various sorts play out as media spectacle, including mega-events like wars, 9/11 and other spectacular terrorist attacks, presidential elections, extreme weather disasters, or, in Spring 2011, political insurrections and upheavals. These spectacles assume a narrative form and become the focus of attention during a specific temporal and historical period, that may only last a few days, but may come to dominate news and information for extended periods of time, as did the O.J. Simpson trial and the Clinton sex/impeachment scandal in the mid1990s, the stolen election of 2000 in the Bush/Gore presidential campaign, or natural and other disasters that have significant destructive effects and political implications, such as Hurricane Katrina, the BP Deepwater Horizon Oil Spill, or the Fukushima-Daiichi nuclear catastrophe. Media spectacles can even become signature events of an entire epoch as were, arguably, the 9/11 terrorist attacks which inaugurated a historical period that I describe as Terror War.

I have argued since 2008 that the key to Barack Obama's success in two presidential elections is that he became a master of the media spectacle, blending politics and performance in carefully orchestrated media spectacles (Kellner 2009 and 2012). Previously, the model of the mastery of presidential spectacle was Ronald Reagan who everyday performed his presidency in a well-scripted and orchestrated daily spectacle. Reagan was trained as an actor and every night Ron and Nancy reportedly practised his lines for the next day's performance as they had done in their Hollywood days. Reagan breezed through the day scripted with a teleprompter for well-orchestrated media events, smiling frequently, and pausing to sound-bite the line of the day.

In the recent 2016 election, Donald Trump has undeniably emerged as a major form of media spectacle and has long been a celebrity and master of the spectacle with promotion of his buildings and casinos from the 1980s to the present, his reality TV shows, self-promoting events, and now his presidential campaign. Hence, Trump has become empowered and enabled to run for the presidency in part because media spectacle has become a major force in US politics, helping to determine elections, government, and more broadly the ethos and nature of our culture and political sphere, and Trump is a successful creator and manipulator of the political spectacle.

I would also argue that in recent years US wars have been orchestrated as media spectacle, recalling Bush Jr's 2003 Iraq shock and awe campaign for one example. Likewise, terrorism has been orchestrated as media spectacle since the 9/11 attack that was the most spectacular and deadly attack on the US heartland in history. As we know too well, school and mass shootings which can be 
seen as a form of domestic terrorism, have become media spectacle with one taking place in 2015 in Virginia on live TV, while the stock market, weather, and every other form of life can become part of a media spectacle. Hence, it is no surprise that political campaigns are being run as media spectacles and that Knights of the Spectacle like Donald Trump deployed the political spectacle to win the presidency.

Trump's biographies reveal that he was driven by a need to compete and win, ${ }^{6}$ and entering the highly competitive real estate business in New York in the 1980s, Trump saw the need to use the media and publicity to promote his celebrity and image. It was a time of tabloid culture and media-driven celebrity and Trump even adopted a pseudonym 'John Baron' to give the media gossip items that touted Trump's successes in businesses, with women, and as a rising man about town. ${ }^{7}$

Trump derives his language and behavior from a highly competitive and ruthless New York business culture and an appreciation of the importance of media and celebrity to succeed in a media-centric hypercapitalism. Hence, to discover the nature of Trump's 'temperament,' personality, and use of language, we should recall his reality TV show The Apprentice which popularized him into a supercelebrity and made 'The Donald' a major public figure for a national audience. Indeed, Trump is the first reality TV candidate who ran his campaign like a reality TV series, boasting during the most chaotic episodes in his campaign that his rallies were the most entertaining, and sending outrageous Tweets into the Twitter-sphere which then dominated the news cycle on the ever-proliferating mainstream media and social networking sites. Hence, Trump is the first celebrity candidate whose use of the media and celebrity star power is his most potent weapon in his improbable and highly surreal campaign. ${ }^{8}$

Trump represents a stage of spectacle beyond Debord's model of spectacle and consumer capitalism in which spectacle has come to colonize politics, culture, and everyday life, with the chief manipulator of the spectacle in the United States, Donald J. Trump, now becoming president and collapsing politics into entertainment and spectacle. In the following sections, I will discuss how this startling development in the history of spectacle took place.

\section{The Apprentice, Twitter and the Summer of Trump}

Since Trump's national celebrity derived in part from his role in the reality TV series The Apprentice, ${ }^{9}$ we need to interrogate this popular TV phenomenon to help explain in turn the Trump phenomenon. The opening theme music, 'For the Love of Money', a 1973 R\&B song by The O'Jays, established the capitalist ethos of the competition for the winning contestant to get a job with the Trump organization, and obviously money is the key to Trump's business and celebrity success. Yet there has been much controversy over how rich Trump is, and so far he has not released his tax returns to quell rumors that he isn't as rich as he 
claims, that he does not contribute as much to charity as he has stated, and that many years he pays little or no tax. ${ }^{10}$

In the original format to The Apprentice, several contestants formed teams to carry out a task dictated by Trump, and each 'contest' resulted with a winner and Trump barking 'you're fired' to the loser. Curiously, some commentators believe that in the 2012 presidential election Barack Obama skilfully beat Mitt Romney because he early on characterized Romney as a billionaire who liked to fire people. This is ironic since this is Trump's signature personality trait in his business, reality TV, and now political career, which has seen him fire two campaign managers and senior advisors in 2016 and the early days of his presidency (see Kellner 2017).

The Apprentice's TV Producer Mark Burnett broke into national consciousness with his reality TV show The Survivor, a neo-Darwinian epic spectacle of alliances, backstabbing, and nastiness, which provides an allegory of how one succeeds in the dog-eat-dog business world in which Donald Trump has thrived, and spectacularly failed as many of the books about him document (see Note 6 below). Both Burnett and Trump share the neo-Darwinian social ethos of nineteenth century ultracompetitive capitalism, with some of Donald Trump's famous witticisms proclaiming:

When somebody challenges you unfairly, fight back-be brutal, be tough-don't take it. It is always important to WIN!

I think everyone's a threat to me.

Everyone that's hit me so far has gone down. They've gone down big league.

I want my generals kicking ass.

I would bomb the shit out of them.

You bomb the hell out of the oil. Don't worry about the cities. The cities are terrible. ${ }^{11}$

In any case, The Apprentice made Trump a national celebrity who became well-known enough to plausibly run for President and throughout the 2016 campaign Trump used his celebrity to gain media coverage through his daily mobilization of political spectacle on the campaign trail. In addition to his campaign's ability to manipulate broadcast media, Trump is also a heavy user of Twitter and he tweets out his messages throughout the day and night. Indeed, Trump may be the first major Twitter candidate, and certainly he is the one using it most aggressively and frequently. Twitter was launched in 2006, but I do not recall it being used in a major way in the 2008 election, although Obama used Facebook and his campaign bragged that he had over a million 'Friends' and used Facebook as part of his daily campaign apparatus. I do not recall, however, previous presidential candidates using Twitter in a big way like Donald Trump, although many have accounts. 
Twitter is a perfect vehicle for Trump as you can use its 140-character framework for attack, bragging, and getting out simple messages or posts that engage receivers who feel they are in the know and involved in TrumpWorld when they get pinged and receive his tweets. When asked at an August 26, 2015, Iowa event as to why he uses Twitter so much, he replied that it was easy, it only took a couple of seconds, and that he could attack his media critics when he 'wasn't treated fairly. Trump has also used Instagram - an online mobile photosharing, video-sharing and social networking service that enables its users to take pictures and videos, and share them on a variety of social networking platforms, such as Facebook, Twitter, Tumblr and Flickr.

Twitter is perfect for General Trump who can blast out his opinions and order his followers what to think. It enables Businessman and Politician Trump to define his brand and mobilize those who wish to consume or support it. Trump Twitter gratifies the need of Narcissist Trump to be noticed and recognized as a master of communication who can bind his warriors into an on-line community. Twitter enables the Pundit-in-Chief to opine, rant, attack, and proclaim on all and sundry subjects, and to subject TrumpWorld to the indoctrination of their Fearless Leader.

Hence, Trump is mastering new media as well as dominating television and old media through his orchestration of media events as spectacles and daily Twitter feed. In Trump's presidential campaign kick-off speech on June 16, 2015, when he announced he was running for President, Trump and his wife Melania dramatically descended the stairway at Trump Towers, and 'The Donald' strode up to a gaggle of microphones and dominated media attention for days with his drama. The opening speech of his campaign made a typically inflammatory remark that held in thrall news cycles for days when he stated:

The US has become a dumping ground for everybody else's problems. [Applause] Thank you. It's true, and these are the best and the finest. When Mexico sends its people, they're not sending their best. They're not sending you. They're not sending you. They're sending people that have lots of problems, and they're bringing those problems with us. They're bringing drugs. They're bringing crime. They're rapists. And some, I assume, are good people.

This comment ignited a firestorm of controversy and a preview of things to come concerning vile racism, xenophobia, Islamophobia, and the other hallmarks of Trump's cacophony of hate. Throughout his campaign, Trump orchestrated political theatre and transformed US politics into spectacle, with his campaign representing another step in the merger between entertainment, celebrity and politics (here Ronald Reagan played a key role, our first actor president).

Trump is, I believe, the first major US presidential candidate to pursue politics as entertainment and thus to collapse the distinction between entertainment, news, and politics, greatly expanding the domain of spectacle theorized by Debord. Furthermore, Trump's use of Twitter, Facebook, and other new forms of 
digital media, social networking, and interactive spectacle expanded the political spectacle to new realms of digitization, participation, and virtuality described by editors and contributors to this book as Spectacle 2.0. Trump's mastery of the politics of the spectacle was evident in his campaign against Hillary Clinton in the 2016 presidential election.

\section{The Spectacle of Election 2016}

Nineteenth century German philosopher Friedrich Nietzsche believed that all social movements are rooted in the herd psychology of resentment which is directed against superior individuals and classes and the state. In particular Nietzsche developed a vitriolic attack on the modern state, finding it to be a 'new idol' that is 'the coldest of all cold monsters', run by 'annihilators' who continuously lie and lie again. 'Everything about it is false', Nietzsche claims (1954 [1883]: 160-163). Nietzsche also consistently attacked German nationalism, writing:

If one spends oneself on power, grand politics, economic affairs, world commerce, parliamentary institutions, military interests - if one expends oneself in this direction the quantum of reason, seriousness, will, self-overcoming that one is, then, there will be a shortage in the other direction (1968b [1889]: 62) that is culture, art, religion, and the development of personality.

Trump's followers appear to be a variant of Nietzsche's mass men seething with resentment, while Donald Trump himself is a cauldron of resentment, who has deeply internalized a lifetime of deep resentments, and thus is able to tap into, articulate, and mobilize the resentments of his followers, in a way that Democrats and other professional politicians have not been able to do. Part of Trump's followers' resentments are directed against politicians, and Trump's ability to tout himself as outside of the political system has been a major theme of his campaign and an apparently successful way to mobilize voters. Yet the Donald Trump presidential reality TV show also stumbled, choked, and went into crisis mode with the onset of the annual presidential debates in which the two finalists get to fight it out to see who will convince the audience that they deserve the ultimate prize, the presidency of the United States. In the age of television, and now new media, US presidential debates have been a gladiatorial spectacle in which the opponents try to destroy each other, while the media personalities who moderate each debate try to positively define themselves and avoid gaffes that could negatively impact their image forever. The first presidential debate on September 27, 2016, was a compelling political media spectacle in which the two candidates showed how they were able to make their case for the presidency under conditions of intense pressure and media focus. From 
the outset, Trump played to the hilt the authoritarian macho, shouting, insulting Clinton, and trying to dominate the procedure. Clinton, however, ignored Trump's bullying and blustering, made her arguments against him, and presented her positions on the issues.

As the debate progressed, Trump exhibited a loss of stamina, rambled, became incoherent, and was unable to cogently respond to Clinton's sharp attacks on his business record, his failure to pay taxes, his atrocious attacks on women, and his lack of qualifications to be president. Trump's unraveling during the first debate presented the media spectacle of the outsider and macho man, not ready for prime time, and losing the debate to the cool professional and qualified politician, who was able to provide coherent answers to questions, and look presidential while Trump faltered and looked increasingly flustered as the debate went on so that by the end he looked like he lacked stamina and was a choker, accusations that he had made against his Republican rivals in the primaries.

The next morning after what commentators on all sides labelled a disappointing, and even disastrous, debate, Trump went on the offensive, lashing out at the debate moderator, complaining about his microphone and threatening to make Bill Clinton's marital infidelity a campaign issue in a spectacle of desperation. There were estimates that 85 million people had watched the debate live on television, and millions more were re-watching it and discussing it at home, work, and online, making it one of the major spectacles in US political history. Clinton was exuberant, campaigning with Bernie Sanders the next day, and presenting a united Democratic Party on the offensive.

Presidential debates are the ultimate shared media spectacle and it would be interesting to see if Trump could recover and gain the offensive in the coming political debates and in the last weeks of the campaign. At different stages, Clinton and Trump had dominated the presidential spectacle, and anything could happen as the spectacle moved toward its conclusion.

Over the weekend of October 8-9,2016, media coverage of the campaign was overwhelmed by the spectacle of a videotape of Trump's bragging of his sexual prowess with women that revealed the full extent of his vulgarity, crudeness, and contempt for women. The front page of the New York Times featured a full account of Trump's sexual bragging in an October 8, 2016 story: 'Tape Reveals Trump Boast About Groping Women,' and television networks and social networking cites played the footage over and over.

A three-minute videotape was found and endlessly replayed of a conversation of trash talk between Trump and Billy Bush, a minor TV celebrity on Access Hollywood and a member of the Bush clan. Trump boasted that his 'star' status allowed him to do what he wanted with women, including married women, telling how, in one case, he 'moved on her like a bitch, but I couldn't get there.' On the whole, sex philosopher Trump asserted that a 'star' like him gets special treatment, and 'You can do anything', including 'grab them by the pussy'. Displaying his vengeful retaliation, he noted that the married woman who managed to resist his cave man charms wasn't really up to 'The Donald's ' 
high standards, as he explained: 'I did try and fuck her. She was married. She's now got the big phony tits and everything.

And so, the media spectacle of the 2016 campaign had devolved into gutter sniping trash talk and Donald Trump demonstrated that, yes, he was an outsider and outside the bounds of decorum, decency, and shame. In a campaign of outrageous sexism, racism, xenophobia, insults, and trash talk would this assault on women and decency finally provoke the viral outrage that went over the top and take Donald Trump into the sewer of filth where even his rabid followers would be loath to follow? Or is this just the way good old boys talk in the locker room, as Trump's surrogates, like thrice-married and serial adulterers Rudi Giuliani and Newt Gingrich insisted? Would the authoritarian populist leader continue to drive his campaign and Trumpite followers forward, or was the spectacle that had created Trump about to devour him?

It turned out, however, that Hillary Clinton would be devoured by media spectacle and her campaign would flounder in the debris of the most explosive media spectacle to drop upon a candidate in recent US presidential history. On Friday, October 29, 2016, FBI Director James Comey dropped a bombshell that is perhaps the most stunning and, for many, outrageous, intervention in a presidential election by a top official of the judicial branch of the government in US presidential history. Director Comey released a letter to twelve Congressmen saying that the FBI had received a collection of emails that the FBI would review to determine if they improperly contained classified information, and that the emails 'appeared to pertain' to Hillary Clinton's email investigation.

Over the past year, the FBI had investigated Clinton's email, and over the summer determined that she was not guilty of any crime concerning her private email server. Many in the FBI and Justice Department were outraged with Comey's rekindling of the Clinton email crisis eleven days before the election. There were immediate leaks to the media that the Justice Department had opposed Comey sending out a letter on an FBI investigation in progress, which was supposed to be secret, and in particular releasing a political bombshell so close to an election when such intervention was specifically prohibited. Further, senior law enforcement officials informed the media that it was unclear if any of the emails were from Mrs. Clinton's private server, and indicated that although Comey said in his letter that the emails 'appear to be pertinent', the FBI had not yet examined them.

Within hours, other government officials leaked that the email trove in question came from a device shared by Anthony Weiner, a former Democratic congressman from New York, and his then wife Huma Abedin, a top aide of Hillary Clinton. Further, the 'unrelated case, which Comey had claimed brought the emails to light, involved an FBI investigation into illicit 'sexting' from Weiner to a 15 -year-old girl in North Carolina. ${ }^{12}$ Trump and his camp were overjoyed by the new bombshell, leading the candidate, who had been complaining that the election was rigged, to concede at a campaign rally in New Hampshire that: 
'Maybe, it's less rigged than I thought... Perhaps, finally, justice will be done.' To the cheers of 'lock her up' from his supporters, Trump claimed: 'Hillary Clinton's corruption is on a scale we have never seen before. We must not let her take her criminal scheme into the Oval Office.

Clinton never recovered from the FBI bombshell and this spectacle blocked her momentum, gave Trump a boost, and played a decisive role in the 2016 US presidential election. Yet there were also revelations just before the election of suspected Russian hacks into the Democratic Party emails, with a release of emails embarrassing to Hillary Clinton, the Democratic National Committee, and Clinton's campaign manager John Podesta, all of which may have turned some voters against Clinton. The alleged Russian interference in the US election was an outrageous scandal that honorable members of Congress and wide sectors of the American people are demanding that the government and media investigate. Indeed, the scandal of Russian interference in the election generated, by March 2017, growing calls for a Special Prosecutor to investigate the ties between the Trump presidential campaign and the Russians, a potential scandal which could well bring down the Trump presidency.

Indeed, on May 17, 2017, former FBI Director Robert Mueller was appointed by the Justice Department as Special Counsel overseeing the investigation into Russian interference in the 2016 United States elections, and there are ongoing investigations as well into the Trump-Russian connections by the FBI and several committees of the House and Senate. This spectacle of scandal and corruption could well bring down the Trump presidency and create an abyss of the spectacle hard to predict or envisage. Indeed, as Trump entered into the fourth month of his presidency, his Achilles heel was clearly his connections and those of his highest officials, and a cadre of lower ones, to Russia and its murderous dictator Vladimir Putin and the Russian government. Trump and Putin are both authoritarians who share a contempt for democratic institutions and freedoms, although it was bizarre and nor yet explained why Trump had chosen so many rabidly pro-Russian members for his administration, and why Trump had throughout the election and into his presidency spoken so highly of Vladimir Putin. Trump had never released his tax returns, and there was still a mystery concerning the financial ties between his campaign and Russia, as well as concerning connections between the Trump organization and Russia. The Russian hack into the 2016 election, described in detail in my book The American Horror Show (Kellner 2017), was perhaps one of the most scandalous foreign interferences in a US presidential election in history, and may unleash the most contentious political spectacle yet to devour a presidential regime.Although there were many other decisive factors in the outcome of the election, including the fact that Clinton ran an uninspiring campaign without a compelling message and the country was suffering from Clinton fatigue, there is no doubt that media spectacle is playing an increasingly important role in US politics, which is now standing on the threshold of an era in which a master of the spectacle, Donald J. Trump stands as President in a presidency 
consumed by spectacle, one that might serve as a sacrifice to the politics of the spectacle that destroys its avatars, just as it creates them. Indeed, Guy Debord might be astonished at the extent to which spectacle has come to dominate politics in high-tech supercapitalist societies of the hyperspectacle which it is our fate to suffer.

\section{Notes}

${ }^{1}$ Guy Debord's The Society of the Spectacle was published in English translation in a pirate edition by Black and Red (Detroit) in 1970 and reprinted many times; another edition appeared in 1983 and a new translation in 1994.

${ }^{2}$ For my concept of media spectacle, see Kellner 2001; 2003a; 2003b; and 2005.

3 In American Nightmare: Donald Trump, Media Spectacle, and Authoritarian Populism (Kellner 2016), I examine how Trump embodies authoritarian populism and has used racism, nationalism, xenophobia, and the disturbing underside of American politics to mobilize his supporters in his successful Republican primary campaign and in the hotly contested 2016 general election. In a successor volume, The American Horror Show: Election 2016 and the Ascendency of Donald J. Trump (Kellner 2017), I discuss how Trump won the 2016 US presidential election and I describe the assembly of his administration and the horrors of the first 100 days of Trump's reign.

${ }^{4}$ I provide accounts of the O.J. Simpson Trial and the Clinton sex/impeachment scandal in the mid-1990s in Kellner 2003b; engage the stolen election of 2000 in the Bush/Gore presidential campaign in Kellner (2001), and describe the 9/11 terrorist attacks and their aftermath in Kellner (2003a).

${ }^{5}$ On the 2011 uprisings, see Kellner (2012).

${ }^{6}$ On Trump's life and career, see D’Antonio 2015; Blair 2000; and Kranish and Fisher 2016. Blair's chapter on 'Born to Compete, op. cit., pp. 223ff., documents Trump's competitiveness and drive for success at an early age.

7 See Fisher and Hobson 2016.

${ }^{8}$ For my take on celebrity politics and the implosion of entertainment and politics in US society, see Kellner 2015: 114-134. The best study of Trump, the media, and his long cultivation and exploitation of celebrity is found in O'Brien, 2016 [2005].

9 Trump's book The Art of the Deal, co-written with Tony Schwartz (New York: Ballantine Books, 2005 [1987]), helped introduce him to a national audience and is a key source of the Trump mythology; see Blair, op. cit., $380 \mathrm{ff}$.

${ }^{10}$ An excellent study of Trump, his scandal-ridden business career, and his shaky finances is found in O'Brien 2016 [2005].

11 Trump 2016, pp 30, 152, 153. 
12 The story of Anthony Weiner and Huma Abedin, and Weiner's 'sexting' addiction that forced him to resign from Congress and then become disgraced again in a run for Mayor of New York, is told in a documentary film Weiner, currently showing on Showtime which became the mustsee film of the day for political junkies. Abedin separated from Weiner in August, 2016, when it emerged that Weiner continued to exchange lewd messages with women on social media despite having seen his online misbehaviours destroying his congressional career and his 2013 mayoral campaign.

\section{References}

Blair, Gwenda. 2000. The Trumps. New York: Simon and Schuster.

D'Antonio, Michael. 2015. Never Enough: Donald Trump and the Pursuit of Success. New York: Thomas Dunne Books.

Debord, Guy. 1970. The Society of the Spectacle. Detroit: Black and Red.

Fisher, Marc and Will Hobson. 2016. 'Donald Trump 'pretends to be his own spokesman to boast about himself.' Some reporters found the calls disturbing or even creepy; others thought they were just examples of Trump being playful.' The Independent, May 13, 2016 at http://www.independent.co.uk/ news/world/americas/us-elections/donald-trump-pretends-to-be-hisown-spokesman-to-boast-about-himself-a7027991.html (accessed August 9, 2016).

Kranish, Michael and Marc Fisher. 2016. Trump Revealed: An American Journey of Ambition, Ego, Money and Power. New York: Scribner.

Kellner, Douglas. 2001. Grand Theft 2000: Media Spectacle and a Stolen Election. Lanham, MD.: Rowman and Littlefield.

Kellner, Douglas. 2003a. Media Spectacle. London and New York: Routledge.

Kellner, Douglas. 2003b. From September 11 to Terror War: The Dangers of the Bush Legacy. Lanham, MD.: Rowman and Littlefield.

Kellner, Douglas. 2005. Media Spectacle and the Crisis of Democracy. Boulder, Col.: Paradigm Press.

Kellner, Douglas. 2009. 'Barack Obama and Celebrity Spectacle'. International Journal of Communication (3): 715-741.

Kellner, Douglas. 2012. Media Spectacle and Insurrection, 2011: From the Arab Uprisings to Occupy Everywhere. London and New York: Continuum/ Bloomsbury.

Kellner, Douglas. 2016. 'Barack Obama, Media Spectacle, and Celebrity Politics' in A Companion to Celebrity, Edited by P. David Marshall and Sean Redmond. Malden, MA. and Oxford, UK. Wiley Blackwell: 114-134.

Kellner, Douglas. 2016. American Nightmare: Donald Trump, Media Spectacle, and Authoritarian Populism. Rotterdam, The Netherlands: Sense Publishers. 
Kellner, Douglas. 2017. The American Horror Show: Election 2016 and the Ascendency of Donald J. Trump. Rotterdam, The Netherlands: Sense Publishers.

Nietzsche, Friedrich. 1954. The Portable Nietzsche. Edited by Walter Kaufmann. New York: Viking Press.

Nietzsche, Friedrich. 1968. Twilight of the Idols. New York: Penguin Books.

O'Brien, Timothy L. 2016 [2005]. TrumpNation: The Art of Being the Donald. New York: Grand Central Publishing.

Trump, Donald. 2016. Quotations From Chairman Trump, edited by Carol Pogash. New York: Rosetta Books.

Trump, Donald. 2005 [1987]. The Art of the Deal, co-written with Tony Schwartz. New York: Ballantine Books. 
